Jurnal Sulolipu : Media Komunikasi Sivitas Akademika dan Masyarakat

Vol. 19 No.12019

e-issn : 2622-6960, p-issn : 0854-624X

\title{
GAMBARAN HIGIENE SANITASI DENGAN KANDUNGAN BAKTERIOLOGIS PADA PERALATAN MAKAN ANGKRINGAN DI KABUPATEN BARRU Indrajayani ${ }^{1}$ dan Haderiah ${ }^{2}$ \\ Jurusan Kesehatan Lingkungan Poltekkes Kemenkes Makassar indrajayani14@gmail.com
}

\section{ABSTRACT}

\begin{abstract}
Angkringan is one of the causes of germs in the food utensils used so that they can cause various hazards such as illness. This study aims to determine the relationship of sanitary hygiene with bacteriological contents on tableware in the angkringan Barru District. This research is observational research with descriptive. The result showed that in personal hygiene of 6 traders, 2 traders (33\%) were eligible and 4 traders (67\%) did not meet the requirements. In the behavioral variable of the 2 merchant traders (33\%) behaved well, and 4 traders (67\%) behaved badly. Besides, there is 1 merchant (17\%) qualified, and 5 traders (83\%) are not eligible. The result of the measurement of bacteriological contents on the tableware of 18 samples (100\%) of cutlery did not meet health requirements. The conclusion in this research that sanitation hygiene conditions with bacteriological contents on angkringan eating equipment in Barru Regency do not meet the health requirements. As for suggestions for traders should pay more attention to hygiene and sanitation equipment to minimize bacterial contamination in eating utensils.
\end{abstract}

Keywords: sanitation hygiene, tableware, bacteriology.

\section{ABSTRAK}

Sanitasi yang tidak memadai dan praktek kebersihan yang buruk pada daerah-daerah perkotaan khususnya pada angkringan, menjadi salah satu penyebab adanya kuman pada peralatan makan yang digunakan sehingga dapat menyebabkan berbagai bahaya seperti penyakit.Penelitian ini bertujuan untuk mengetahui hubungan higiene sanitasi dengan kandungan bakteriologis pada peralatan makan di angkringan Kabupaten Barru. Penelitian ini merupakan penelitian observasional dengan pendekatan deskriptif. Hasil penelitian diperoleh bahwa pada variabel higiene personal dari 6 pedagang, 2 pedagang $(33 \%)$ memenuhi syarat dan 4 pedagang $(67 \%)$ tidak memenuhi syarat. Pada variabel perilaku penjamah 2 pedagang (33\%) berprilaku baik, dan 4 pedagang $(67 \%)$ berprilaku buruk. Selain itu pada variabel proses pencucian peralatan makan terdapat 1 pedagang $(17 \%)$ memenuhi syarat, dan 5 pedagang $(83 \%)$ tidak memenuhi syarat. Hasil pengukuran kandungan bakteriologis pada peralatan makan dari 18 sampel (100\%) alat makan tidak memenuhi syarat kesehatan. Kesimpulan dalam penelitian ini yaitu kondisi higiene sanitasi dengan kandungan bakteriologis pada peralatan makan angkringan di Kabupaten Barru tidak memenuhi syarat kesehatan. Adapun saran untuk para pedagang hendaknya lebih memperhatikan higiene dan sanitasi peralatan guna meminimalisir kontaminasi bakteri pada peralatan makan.

Kata kunci : higiene sanitasi, peralatan makan, bakteriologis.

PENDAHULUAN

Makanan adalah bahan yang
biasanya berasal dari hewan atau
tumbuhan, yang dimakan olek makhluk hidup untuk mendapatkan tenaga dan nutrisi. Cairan yang dipakai untuk maksud ini sering disebut minuman, tetapi kata 'makanan' juga biasa dipakai. Istilah ini kadang-kadang dipakai dengan kiasan, seperti "makanan untuk pemikiran". Kecukupan makanan dapat dinilai dengan status gizi secara antropometri (Nurul, 2017).

Higiene dan sanitasi tidak dapat dipisahkan satu dengan yang lain karena erat kaitannya. Adapun faktor-faktor yang perlu diperhatikan untuk dapat menyelenggarakan sanitasi makanan yang efektif adalah faktor makanan, faktor manusia, dan faktor peralatan (Chandra, 2006).
Peranan peralatan makan dalam pedagang makanan merupakan bagian yang tak terpisahkan dari prinsip-prinsip penyehatan makanan (foodhygiene). Menurut Djajadiningrat (1989) dalam Desmaslimah (2009) setiap peralatan makan (piring,gelas,sendok) haruslah selalu dijaga kebersihannya setiaV Bp saat digunakan. Alat makan (piring, gelas, sendok) yang kelihatan bersih belum merupakan jaminan telah memenuhi persyaratan kesehatan, untuk itu pencucian peralatan sangat penting diketahui secara mendasar, dengan pencucian secara baik akan menghasilkan peralatan yang bersih dan sehat. Dengan menjaga kebersihan peralatan makan (piring,gelas dan sendok), berarti telah membantu mencegah pencemaran atau kontaminasi makanan yang dikonsumsi. 
Jurnal Sulolipu : Media Komunikasi Sivitas Akademika dan Masyarakat

Vol. 19 No.12019

e-issn : 2622-6960, p-issn : 0854-624X

Masyarakat memilki 2 sistem pencucian, yaitu secara bilasan air mengalir dan cara perendaman. Tak terkecuali bagi para pedagang makanan seperti restoran dan jajanan kuliner lainnya juga menerapkan metode pencucian tersebut (Jimmi, 2013).

Berdasarkan hasil survey lokasi di angkringan Kabupaten Barru yang dilakukan pada tanggal 3 Desember 2017, disekeliling lokasi angkringan terdapat laut yang ditepian laut banyak sampah yang berserakan akibat penjual yang membuang sampah sembarangan. Penjamah makan kurang memperhatikan kebersihan diri dan tidak menggunakan APD pada saat melakukan pengolahan makanan. Terkait dengan proses pencucian peralatan makan masih menggunakan tempat yang sederhana, kemudian proses pencucian peralatan makan hanya menggunakan satu alat pencucian. Sehingga pada permasalahan tersebut peneliti tertarik untuk melakukan penelitian, yaitu "Gambaran Higiene Sanitasi Dengan Kandungan Bakteriologis Pada Peralatan Makan Angkringan di Kabupaten Barru".

\section{Bahan dan Metode}

1. Lokasi Penelitian:

Lokasi pengambilan sampel peralatan makan dilakukan di angkringan Mangempang, kecamatan Barru, Kabupaten Barru dan lokasi untuk melakukan pemeriksaan kandungan bakteriologis pada peralatan makan dilakukan di Laboratorium Mikrobiologi Jurusan Kesehatan Lingkungan Politeknik Kesehatan Makassar.

\section{Desain dan Variabel Penelitian}

Jenis penelitian yang digunakan dalam penelitian ini adalah jenis penelitian observasional dengan pendekatan deskriptif dimana variabel bebas dan variabel terikat dihubungkan secara bersamaan untuk mengetahui hubungan antara variabel-variabel tersebut.

Adapun variabel penelitian pada penelitian ini terdiri dari 3 variabel. Yaitu variabel bebas yang terdiri dari higiene personal, perilaku penjamah dan proses pencucian. Variabel terikat yaitu kandungan bakteriologis pada peralatan makan, serta variabel pengganggu yaitu kualitas air.

3. Populasi dan Sampel

Populasi dalam penelitian ini adalah semua pedagang di Angkringan Kabupaten Barru yang berjumlah sebanyak 50 pedagang.

Sampel dalam penelitian ini sebanyak 6 pedagang dengan 3 jenis alat makan, penentuan jumlah sampel dalam penelitian ini ditentukan dengan menggunakan teknik purposive sampling, yaitu didasarkan pada penggunaan sumber air, pedagang yang memakai sumber air yang sama, akan diambil 1 sampel untuk mewakili sampel yang lainnya.

4. Pengumpulan data

a. Data Primer

Data primer diperoleh dari hasil observasi langsung serta hasil pemeriksaan kandungan bakteriologis pada peralatan makan dari laboratorium mikrobiologi.

b. Data Sekunder

Data sekunder diperoleh melalui penelusuran kepustakaan berupa referensi hasil penelitian sebelumnya, jurnal, artikel, maupun laporan pemerintah yang terkait seperti dinas kesehatan provinsi dan kota.

\section{Analisis Data}

Data yang telah diolah dianalisa secara deskriptif yaitu dengan mengetahui gambaran antara higiene sanitasi dengan kandungan bakteriologis pada peralatan makan angkringan di Kabupaten Barru.

\section{Hasil Penelitian}

1. Higiene Personal Penjamah Tabel 1

Distribusi Higiene Personal Penjamah pada Pedagang Angkringan Kabupaten Barru

\begin{tabular}{cccc}
\hline \hline No. & $\begin{array}{l}\text { Higiene } \\
\text { Personal }\end{array}$ & Frekuensi & $\begin{array}{l}\text { Persentase } \\
(\%)\end{array}$ \\
\hline 1 & $\begin{array}{l}\text { Memenuhi } \\
\text { Syarat }\end{array}$ & 2 & 33 \\
2 & 4 & 67 \\
$\begin{array}{l}\text { Tidak } \\
\text { Memenuhi } \\
\text { Syarat }\end{array}$ & $\mathbf{6}$ & $\mathbf{1 0 0}$ \\
\hline \multicolumn{1}{c}{ Total } & \\
\hline
\end{tabular}

Sumber: Data Primer,2018 
Jurnal Sulolipu : Media Komunikasi Sivitas Akademika dan Masyarakat

Vol. 19 No.12019

e-issn : 2622-6960, p-issn : 0854-624X

\section{Perilaku Penjamah}

Tabel 2

Distribusi Higiene Personal Penjamah pada Pedagang Angkringan Kabupaten Barru

\begin{tabular}{|c|c|c|c|c|}
\hline$\overline{\text { No }}$ & $\begin{array}{l}\text { Perilaku } \\
\text { Penjamah }\end{array}$ & & Frekuensi & $\begin{array}{l}\text { Persentase } \\
(\%)\end{array}$ \\
\hline 1 & Baik & & 2 & 33 \\
\hline 2 & Buruk & & 4 & 67 \\
\hline & & Total & 6 & 100 \\
\hline
\end{tabular}

Sumber: Data Primer,2018

\section{Proses Pencucian Peralatan Makan Tabel 3 \\ Distribusi Proses Pencucian Peralatan Makan pada Pedagang Angkringan Kabupaten Barru}

\begin{tabular}{llcc}
\hline \hline No & $\begin{array}{l}\text { Proses Pencucian } \\
\text { Peralatan Makan }\end{array}$ & Frekuensi & $\begin{array}{l}\text { Persentase } \\
(\%)\end{array}$ \\
\hline 1 & Memenuhi Syarat & 1 & 17 \\
2 & $\begin{array}{l}\text { Tidak Memenuhi } \\
\text { Syarat }\end{array}$ & 5 & 83 \\
\hline \multicolumn{1}{c}{ Total } & 6 & $\mathbf{1 0 0}$ \\
\hline \multicolumn{4}{c}{ Sumber: Data Primer 2018 }
\end{tabular}

Sumber: Data Primer,2018

\section{Kandungan Bakteriologis pada Peralatan Makan}

Berdasarkan hasil penelitian dari 18 sampel alat makan di dapatkan hasil pemeriksaan laboratorium mengenai kandungan bakteriologis pada peralatan makan yaitu pada piring, sendok dan gelas yang diambil dari 6 pedagang di angkringan Kabupaten Barru dengan 3 jenis alat makan yaitu 18 sampel (100\%) alat makan tidak memenuhi syarat.

\section{Pembahasan}

1. Higiene Personal Penjamah

Berdasarkan hasil observasi yang dilakukan pada pedagang angkringan Kabupaten Barru terkait higiene personal penjamah didapatkan hasil dari 6 pedagang diketahui 2 pedagang dengan persentase (33\%) yang memenuhi syarat dan 4 pedagang dengan persentase (67\%) tidak memenuhi syarat.

Dari 6 pedagang didapatkan hasil 4 pedagang dengan persentase $(67 \%)$ yang menderita penyakit menular batuk, pilek, diare, influenza, penyakit perut dan sejenisnya. Apabila penjamah makan menderita penyakit menular seperti batuk dan influenza dapat mengakibatkan perpindahan mikroba dari mulut ke alat makan secara langsung. Untuk menghindari hal tersebut dianjurkan bagi pedagang hendaknya menggunakan masker atau penutup mulut. Sebanyak 6 pedagang $(100 \%)$ tidak memakai sarung tangan, ditemukan pula 6 pedagang (100\%) mencuci tangan tanpa menggunakan sabun. Mencuci tangan tanpa menggunakan sabun mempunyai andil yang besar dalam melakukan perpindahan kontaminan dari manusia ke alat makan.

Hasil penelitian menunjukkan 3 pedagang ( $50 \%)$ memiliki kuku panjang. Menurut penelitian yang dilakukan oleh Infectious Disease Society of Amerika, 2015 kuku yang lebih panjang dari tiga millimeter diluar ujung jari mengandung bakteri berbahaya. Hasil dari penelitian ini juga menunjukkan kebanyakan orang tidak mencuci tangan dengan baik untuk menyingkirkan semua kuman dibawah kuku. Kuku panjang berpotensi menyebabkan sejumlah masalah kesehatan karena kuku menjadi tempat sempurna bagi kuman dan kotoran untuk tinggal. Para ahli kesehatan setuju bahwa kuku harus dipotong pendek dan tetap bersih. Maka dari itu hendaknya para pedagang harus memperhatikan kebersihan kuku guna menghindari adanya kontaminasi bakteri pada alat makan (IDSA, 2016).

Penelitian ini sejalan dengan penelitian yang dilakukan oleh Mayfika, dkk (2015) tentang hubungan hygiene sanitasi dengan kualitas bakteriologis pada alat makan pedagang di wilayah sekitar kampus Undip Tembalang menunjukkan bahwa dari 46 sampel yang diuji terdapat 31 sampel (67\%) higiene penjamah tidak memenuhi syarat dan 5 sampel (11\%) yang memenuhi syarat. Sebanyak 100\% ditemukan adanya kuman pada alat makan. 
Jurnal Sulolipu : Media Komunikasi Sivitas Akademika dan Masyarakat

Vol. 19 No.12019

e-issn : 2622-6960, p-issn : 0854-624X

\section{Perilaku Penjamah}

Berdasarkan hasil observasi yang dilakukan pada pedagang angkringan Kabupaten Barru terkait perilaku penjamah didapatkan hasil dari 6 pedagang diketahui 2 pedagang dengan persentase (33\%) yang berprilaku baik dan 4 pedagang dengan persentase $(67 \%)$ yang berprilaku buruk.

Kebersihan penjamah merupakan kunci dalam pengolahan makanan yang aman dan sehat. Dengan demikian penjamah harus mengikuti prosedur yang memadai untuk mencegah kontaminasi pada alat makan yang akan digunakan. Prosedur yang penting bagi pedagang adalah pencucian tangan. Berdasarkan hasil observasi yang telah dilakukan ditemukan kebiasaan pedagang mencuci tangan sebelum dan setelah bekerja sebanyak 5 pedagang (83\%) dan tidak mencuci tangan sebanyak 1 pedagang (17\%), akan tetapi berdasarkan hasil pengamatan pedagang di angkringan sebanyak 6 pedagang (100\%) mencuci tangan tidak menggunakan sabun.

Sebanyak 6 pedagang dengan persentase (100 \%) tidak mengeringkan tangan menggunakan lap bersih, dan 6 pedagang (100\%) ditemukan tidak menggunakan lap bersih ketika bekerja. Hasil penelitian juga menunjukan bahwa 3 pedagang ( $50 \%$ ) sering menggaruk anggota badannya pada saat bekerja.

Kebiasaan tangan dari pekerja pengelola pangan mempunyai andil yang besar dalam peluang melakukan perpindahan kontaminan dari manusia ke alat makan. Kebiasaan tangan ini dikaitkan dengan pergerakanpergerakan tangan yang tidak disadari seperti menggaruk kulit, menggosok hidung, merapikan rambut, menyentuh atau meraba pakaian dan hal- hal yang serupa. Karena banyaknya aktivitas yang dapat dilakukan oleh tangan, maka dari itu hendaknya lebih memperhatikan kebersihan tangannya.

3. Proses Pencucian Peralatan Makan
Proses pencucian peralatan makan yang dilakukan di Angkringan Kab. Barru masih kurang baik karena pada proses pencucian peralatan tidak memperhatikan pergantian air bilasan dan tidak ada upaya desinfektan terhadap peralatan makan baik dengan pembilasan dengan air yang mengandung kaporit. Adapun kualitas bakteriologis air pencucian yang digunakan pedagang diperoleh hasil 6 air pencucian (100\%) positif bakteri coliform. Berdasarkan Permenkes RI NO 32 Tahun 2017 tentang standar baku mutu kesehatan lingkungan dan persyaratan kesehatan air untuk keperluan hygiene dan sanitasi, kolam renang, solus per aqua, dan permandian umum yaitu 50CFU/100 $\mathrm{ml}$.

Berdasarkan hasil observasi ditemukan dari 6 pedagang (100\%) peralatan makan tidak dikeringkan menggunakan lap yang bersih, dimana lap tersebut tidak di cuci atau diganti setiap hari, dan peralatan makan juga disimpan ditempat yang lembab, dan dalam keadaan yang tidak tertutup. Penyimpanan peralatan makan juga $100 \%$ disimpan pada tempat yang terbuka sehingga memungkinkan tercemarnya oleh kuman dan hewan pengganggu lainnya.

Adanya bakteri disebabkan karena higiene sanitasi peralatan makan yang kurang baik serta pengetahuan penjamah tentang higiene dan sanitasi peralatan makan yang rendah. Kontaminasi bakteri terhadap peralatan makan menjadikan peralatan makan tidak layak untuk dipergunakan, karena akan berdampak langsung bagi manusia pengguna peralatan makan. Angkringan yang menyediakan bermacam-macam makanan tidak menjadi jaminan kualitas makanannya itu baik. Kontaminasi dapat terjadi setiap saat, salah satunya dari peralatan makan yang digunakan tidak memenuhi syarat kesehatan.

\section{Kandungan Bakteriologis pada} Peralatan Makan

Berdasarkan hasil pemeriksaan jumlah kuman pada peralatan makan 
Jurnal Sulolipu : Media Komunikasi Sivitas Akademika dan Masyarakat

Vol. 19 No.12019

e-issn : 2622-6960, p-issn : 0854-624X

piring, sendok, dan gelas yang berasal dari pedagang Angkringan Kabupaten Barru diketahui proporsi peralatan makan yang terdapat kuman dengan jumlah sampel 18 alat makan semuanya positif ada kandungan bakteriologisnya.

Berdasarkan hasil pemeriksaan kualitas bakteriologis pada alat makan sendok,piring dan gelas setelah pencucian dan siap digunakan semua dinyatakan tidak memenuhi syarat berdasarkan Permenkes RI No.1096/Menkes/Per/VI/2011 tentang higiene sanitasi jasa boga. Hal ini disebabkan perilaku penjamah dan teknik pencucian yang kurang baik pada saat proses pencucian peralatan makan.

Pada pemeriksaan jumlah kuman peralatan makan sangat tinggi hal ini dapat disebabkan oleh perilaku penjamah pada saat proses pencucian dan setelah pencucian peralatan makan disimpan atau ditiriskan sampai kering ditempat terbuka sehingga dapat terkontaminasi oleh debu, bakteri dan vektor pembawa penyakit dan dapat pula disebabkan pada tahap pengeringan, kontaminasi tempat penyimpanan yang lembab dan tidak terlindung dari vektor pengganggu, serta bisa pula kontaminasi akhir sebelum peralatan tersebut digunakan berasal dari kondisi higiene personal penjamah saat kontak langsung dengan peralatan. Dengan demikian proses yang tidak memenuhi syarat dapat mengakibatkan besarnya jumlah kuman pada peralatan makan, sehingga sering kali tidak memperhatikan proses pencucian peralatan makan

\section{Kesimpulan dan Saran \\ 1. Kesimpulan}

Berdasarkan penelitian yang telah dilakukan maka dapat ditarik beberapa kesimpulan sebagai berikut :

a. Variabel higiene personal dapat disimpulkan bahwa 2 pedagang (33\%) memenuhi syarat dan 4 pedagang $(67 \%)$ tidak memenuhi syarat di angkringan Kabupaten Barru.

b. Variabel perilaku penjamah dapat disimpulkan bahwa 2 pedagang $(33 \%)$ memenuhi syarat dan 4 pedagang $(67 \%)$ tidak memenuhi syarat variabel perilaku penjamah di angkringan Kabupaten Barru.

c. Variabel proses pencucian dapat disimpulkan bahwa 1 pedagang (17\%) memenuhi syarat dan 5 pedagang (83\%) tidak memenuhi syarat variabel proses pencucian di angkringan Kabupaten Barru.

\section{Saran}

a. Bagi Pemerintah, sebaiknya mengadakan upaya peningkatan pengetahuan tentang higiene dan sanitasi sehingga dapat menghindari penyakit serta melakukan pengawasan dan pembinaan terhadap pedagang di Angkringan Kabupaten Barru.

b. Bagi pedagang, hendaknya memperhatikan higiene personal seperti kebersihan anggota badan dan kelengkapan APD (Alat Pelindung Diri) yang seharusnya digunakan, agar dapat meminimalisir kontaminan pada peralatan makan.

c. Hendaknya para pedagang lebih memperhatikan kondisi sarana sanitasi khususnya air yang digunakan pada saat pencucian dan kondisi tempat penyimpanan peralatan, karna kondisi sanitasi yang buruk dapat menjadi pemicu adanya bakteri pada peralatan makan.

d. Bagi peneliti selanjutnya, hendaknya melakukan penelitian mengenai tingkat pengetahuan dan sikap pedagang. 
Jurnal Sulolipu : Media Komunikasi Sivitas Akademika dan Masyarakat

Vol. 19 No.12019

e-issn : 2622-6960, p-issn : 0854-624X

\section{DAFTAR PUSTAKA}

A. Muri Yusuf. 2014. Metode Penelitian Kuantitatif, Kualitatif, dan Penelitian Gabungan. Jakarta : Prenadamedia Grup

Annisa Andriyani. 2009. Pengaruh Larutan Detergent dan Larutan Klorin Pada Proses Pencucian Alat Makan dengan Metode Three Compartement Sink Terhadap Penurunan Jumalah Angka Kuman Alat Makan Di RS PKU Muhammadiayah Surakarta. Jurnal IImu Kesehatan. 5 (1). (online) http://www.jurnal.stikes-aisyiyah.ac.id/. Diakses 25 Desember 2017.

IDSA. 2016. Nail Health. (online). http://www.idsociety.org Diakses pada 26 Juni 2018

BPOM. 2003. Mikrobiologi Pangan. Jakarta : Direktorat Surveilans dan Penyuluhan Keamanan Pangan dan Bahan Berbahaya.

Cecep Dani Sucipto. 2015. Keamanan Pangan Untuk Kesehatan Manusia. Yogyakarta: Gosyen Publishing.

Chairini Tri Cahyaningsih, Haripurnomo Kushadiwijaya dan Abu Tholib. 2009. Hubungan Higiene Sanitasi dan Perilaku Penjamah Makanan dengan Kualitas Bakteriologis Peralatan Makan di Warung Makan. Jurnal. IImu Kesehatan Masyarakat. 25 (4) :180-188. (online) https://journal.ugm.ac.id. Diakses pada 27 Desember 2017

Chandra Budiman. 2006. Pengantar Kesehatan Lingkungan. Jakarta : EGC.

Desmaslima Pohan S. 2009. Pemeriksaan Escherichia coli pada Usapan Peralatan Makan Yang Digunakan Oleh Pedagang Makanan di Pasar Petisah Medan. Skripsi. Fakultas Kesmas Universitas Sumatera Utara. (online) http://repository.usu.ac.id/. Diakses 12 Desember 2017.

Dwidjoseputro. 2005. Dasar-dasar Mikrobiologi. Jakarta : Djambatan

H. Anwar, dkk. 1990. Pedoman Bidang Studi Sanitasi Makanan dan Minuman Pada Institusi Tenaga Sanitasi. Jakarta : Pusdiknakes

Henny J. Tumelap. 2011. Kondisi Bakteriologis Peralatan Makan Di Rumah Makann Jombang Tikala Manado. JKL. 1 (1). $20 \quad$ - $27 . \quad$ (online). https://media.neliti.com/media/publications/104954-ID-kondisi-bakteriologik-peralatan-makandi.pdf. Diakses pada 27 juni 2018

Hiasinta A. Purnawijayanti. 2001. Sanitasi Hygiene dan Keselamatan Kerja Dalam Pengolahan Makanan. Yogyakarta: Kanisius

Jimmi Tomam Azari. 2013. Studi Komparatif Pencucian Alat Makan dengan Perendaman dan Air Mengalir terhadap Jumlah Kuman Pada Alat Makan di Warung Makan Bu Am Gonilan. Artikel Publikasi Ilmiah. Universitas Muhammadiyah Surakarta. (online) http://eprints.ums.ac.id/. Diakses 23 Desember 2017.

Kemenkes. 2017. Kejadian Luar Biasa Keracunan di Kota Makassar. (online) http://pusatkrisis.kemkes.go.id/. Diakses 25 Desember 2017.

Mayvika Farah Fadhila, Nur Endah Wahyuningsih, dan Yusniar Hanani D. 2015. Hubungan Higiene Sanitasi dengan Kualitas Bakteriologis pada Alat Makan Pedangang di Wilayah Sekitar Kampus UNDIP Tembalang. Jurnal Kesehatan Masyarakat. 3 (3): 769- 776. (online) https://media.neliti.com/. Diakses 20 Desember 2017. 
Jurnal Sulolipu : Media Komunikasi Sivitas Akademika dan Masyarakat

Vol. 19 No.12019

e-issn : 2622-6960, p-issn : 0854-624X

Nurul Amaliah. 2017. Penyehatan Makanan Dan Minuman-B. (online) https://books.google.co.id/. Diakses 29 Desember 2017.

Nur Laila, Agustina. 2013. Hubungan Antara Hygiene Sanitasi Penjamah Dan Sanitasi Makanan Dengan Keberadaan Bakteri Echerchia Coli. Skripsi. Jurusan IImu Kesehatan Masyarakat. Universitas Negri Semarang. (online). http://lib.unnes.ac.id/8040/. Diakses pada tanggal 26 Juni 2018

Prasetyo Hadi Atmoko. 2017. Peningkatan Higene Sanitasi sebagai Upaya Menjaga Kualitas Makanan dan Kepuasan Pelanggan Di Rumah makan Dhamar Palembang. Jurnal Khasanah IImu. 8 (1) : 1-9. (online) http://ejournal.bsi.ac.id/. Diakses 17 Desember 2017.

Republik Indonesia. 2003. Keputusan Menteri Kesehatan Republik Indonesia Nomor 1098 tentang Persyaratan Hygiene sanitasi Rumah Makan dan Restoran.

Republik Indonesia. 2011. Keputusan Menteri Kesehatan Republik Indonesia Nomor 1096 tentang Higiene Sanitasi JasaBoga.

Republik Indonesia. 2003. Keputusan Menteri Kesehatan Republik Indonesia Nomor 942 tentang Pedoman Persyaratan Hygene Sanitasi Makanan Jajanan.

Republik Indonesia. 2017. Peraturan Menteri Kesehatan Republik Indonesia Nomor 32 Tentang Standar Baku Mutu Kesehatan Lingkungan Dan Persyaratan Kesehatan Air Untuk Keperluan Hygiene Dan Sanitasi, Kolam Renang, Solus Per Aqua, Dan Permandian Umum.

Retno Widyati. 2002. Higene dan Sanitasi. Umum dan Perhotelan. Jakarta: Grasindo. (online) https://www.bukupedia.com. Diakses 23 Desember 2017.

Rizsa Puspitaningtyas. 2015. Upaya Penjamah Makanan Dalam Menjaga Kualitas Ditinjau Dari Aspek Food Safety Pada Warung Makan di Sekitar Universitas Negeri Semarang. Skripsi. Jurusan IImu Kesehatan Masyarakat Universitas Negeri Semarang. (online). http://lib.unnes.ac.id/20323/1/6411411124-S.pdf. Diakses pada 26 Juni 2018.

Soekidjo Notoatmodjo. 2003. IImu Kesehatan Masyarakat. Jakarta : Rineka Cipta

Sugiyono. 2010. Metode Penelitian Kuantitatif Kualitatif dan R\&D. Bandung : CV Alfabeta

Sumanto. 2014. Teori Dan Aplikasi Metode Penelitian. Yogyakarta: Center of Academic Publishing Service

Wahyuni Sahani, dkk. 2017. Panduan Penulisan Proposal Penelitian Skripsi. Makassar: Kementerian Kesehatan Republik Indonesia Politeknik Kesehatan Kemenkes Makassar Jurusan Kesehatan Lingkungan.

WHO. 2017. Food Safety. (online) http://www.who.int/mediacentre. Diakses 27 Desember 2017.

Yulia. 2016. Higiene Sanitasi Makanan, Minuman Dan Sarana Sanitasi Terhadap Angka Kuman Peralatan Makan Dan Minum Pada Kantin. Jurnal Vokasi Kesehatan. 2 (1): 55-61. (online). http://ejournal.poltekkes-pontianak.ac.id. Diakses 13 Desember 2017.

Zaenab, Inayah, dan Haderiah. 2015. Buku Panduan Praktikum PMM - A. Makassar: Kementerian Kesehatan Republik Indonesia Politeknik Kesehatan Kemenkes Makassar Jurusan Kesehatan Lingkungan. 